\title{
IMPROVEMENT IN QUALITY-OF-LIFE AFTER LAPAROSCOPIC NISSEN FUNDOPLICATION
}

\author{
Guilherme Tommasi KAPPAZ, Rubens Antonio Aissar SALLUM, Sergio SZACHNOWICZ, \\ Julio Rafael Mariano ROCHA and Ivan CECCONELLO
}

\begin{abstract}
Context - Evaluating quality of life after surgery for gastroesophageal reflux is fundamental, since improvement of symptoms is the main goal of treatment. Objective - To compare the satisfaction of patients operated for GERD, interviewed at the office, with patients interviewed by telephone. Methods - One hundred and seventy-eight patients were submitted to laparoscopic Nissen fundoplication. Ninety patients were found, and 45 agreed to come to the hospital's office. The other 45 patients were interviewed by telephone. Quality of life was evaluated using three methods: The GERD-HRQL questionnaire, translated to Portuguese; question "If you could choose it today, would you do surgery again?"; and question "If you could classify your symptom improvement between 0 and 10, which grade would you give?" Patients were divided in group A (office interview) and B (telephone interview). Statistical analysis was performed. Results - The average GERD-HRQL score in group A was 6.29, while in group B was 14.09 $(P=0.002)$. There was no statistical difference between groups A and B regarding patients choice of doing the surgery again $(P=0.714)$ and their grade of postoperative symptom improvement $(P=0.642)$. Conclusion - The overall postoperative satisfaction was high. The GERD-HRQL questionnaire might not be suitable for application by telephone in our population, and based on other analyzes, the satisfaction and quality of life of patients interviewed at the office or by telephone was similar.
\end{abstract}

HEADINGS - Gastroesophageal reflux. Fundoplication. Quality of life.

\section{INTRODUCTION}

Laparoscopic Nissen fundoplication is the preferred surgical treatment for the Gastroesophageal Reflux Disease (GERD) treatment. Limited to a small percentage of GERD patients, its use has increased since the start of the laparoscopy surgery era, although a recent decline has been reported ${ }^{(3)}$. The main objectives of the surgical treatment are the reduction of symptoms and improvement in qualityof-life. Patients reported good results after surgery, with significant reduction of symptoms in $80 \%$ to $95 \%$ on five to 10 -year follow-up ${ }^{(2,7,8)}$. However, a significant number of patients have either recurrence of symptoms or the development of new symptoms that were not present before surgery, with impact on quality-of-life. The laparoscopic Nissen procedure, although well standardized, is performed in a dynamic region of the upper abdomen, subjected to continuous movement with breathing, with risks of migration and detachment of the flap, which could impact patient long-term satisfaction ${ }^{(12)}$.

The Gastroesophageal Reflux Disease-Health Related Quality of Life (GERD-HRQL) questionnaire was developed as a concise instrument, which focus on the typical symptoms of the disease, and can be used to evaluate the outcome of treatment for GERD ${ }^{(5,14)}$. It was translated and validated to Brazilian Portuguese language in $2007^{(10)}$.

In Brazil, evaluating quality-of-life with questionnaires can be difficult, since many patients cannot come to the hospital when asked for, change addresses without updating it on the hospital database, live far from the hospital where they were treated or have incomplete literacy. Accordingly, the use of instruments that can be applied by telephone, which is widely available, could increase the response rate of these questionnaires.

The aim of this study was to evaluate the general satisfaction of patients submitted to laparoscopic Nissen fundoplication for GERD, and to compare the differences in the satisfaction grade among then when interviewed at the office or by telephone.

\section{METHODS}

The study was previously approved by the local ethics committee at Hospital das Clínicas, University of São Paulo. Between 2005 and 2009, 178 patients were submitted to laparoscopic Nissen fundoplication in our department. The inclusion criteria were minimal follow-up of one year and no previous esophageal

Declared conflict of interest of all authors: none

Hospital das Clinicas, Universidade de São Paulo - Gastroenterologia, Divisão de Cirurgia Esofágica

Correspondence: Guilherme Tommasi Kappaz. Hospital das Clinicas, Universidade de São Paulo - Gastroenterologia, Divisão de Cirurgia Esofágica. Avenida Doutor

Enéas de Carvalho Aguiar, 23, $9^{\circ}$ andar - CEP 05403-000 - São Paulo, SP, Brasil. E-mail: gtkappaz@yahoo.com 
or gastric surgery. All patients had either typical symptoms of GERD or positive $\mathrm{pH}$-metry studies to confirm the presence of the disease.

Patient's records were reviewed, and contact was attempted with all of them, either by telephone or mail. Ninety patients were found, and 45 agreed to come to the hospital's office for an interview. The other 45 patients were interviewed by telephone. All patients at the office filled a permission form, and patients interviewed by telephone agreed to a verbal permission form that was read to them before the start of the study, as requested by the ethics committee. In both groups, the interviews were done by the same researcher.

Quality of life was evaluated using three methods:

1. The GERD-HRQL questionnaire, translated to Portuguese ${ }^{(10)}$. The questionnaire includes ten questions with scores between 0 and 5 for each question, with total score ranging from 0 to 50 . It also contains an extra question that asks patients whether they are satisfied, neutral or dissatisfied with their present condition (Figure 1).

\begin{tabular}{|c|c|c|c|c|c|c|}
\hline Question & \multicolumn{6}{|c|}{ Score } \\
\hline 1. How bad is your heartburn? & 0 & 1 & 2 & 3 & 4 & 5 \\
\hline 2. Heartburn when lying down? & 0 & 1 & 2 & 3 & 4 & 5 \\
\hline 3. Heartburn when standing up? & 0 & 1 & 2 & 3 & 4 & 5 \\
\hline 4. Heartburn after meals? & 0 & 1 & 2 & 3 & 4 & 5 \\
\hline $\begin{array}{l}\text { 5. Does heartburn change your } \\
\text { diet? }\end{array}$ & 0 & 1 & 2 & 3 & 4 & 5 \\
\hline $\begin{array}{l}\text { 6. Does heartburn wake you from } \\
\text { sleep? }\end{array}$ & 0 & 1 & 2 & 3 & 4 & 5 \\
\hline $\begin{array}{l}\text { 7. Do you have difficulty } \\
\text { swallowing? }\end{array}$ & 0 & 1 & 2 & 3 & 4 & 5 \\
\hline $\begin{array}{l}\text { 8. Do you have pain with } \\
\text { swallowing? }\end{array}$ & 0 & 1 & 2 & 3 & 4 & 5 \\
\hline $\begin{array}{l}\text { 9. Do you have bloating or gassy } \\
\text { feelings? }\end{array}$ & 0 & 1 & 2 & 3 & 4 & 5 \\
\hline $\begin{array}{l}\text { 10. If you take medication, does } \\
\text { this affect your daily life? }\end{array}$ & 0 & 1 & 2 & 3 & 4 & 5 \\
\hline $\begin{array}{l}\text { 11. How satisfied are you with } \\
\text { your present condition? }\end{array}$ & $\begin{array}{l}\text { Sati } \\
\text { Neu } \\
\text { Diss }\end{array}$ & & & & & \\
\hline
\end{tabular}

FIGURE 1. Original Gastroesophageal Reflux Disease - Health Related Quality of Life questionnaire

Scale:

0 - No symptoms

1 - Symptoms noticeable, but not bothersome

2 - Symptoms noticeable and bothersome, but not every day

3 - Symptoms bothersome every day

4 - Symptoms affect daily activities

5 - Symptoms are incapacitating, unable to do daily activities

2. Question "If you could choose it today, would you do surgery again?"

3. Question "If you could classify your symptom improvement between 0 and 10, which grade would you give?"

Patients who could not clearly comprehend a specific inquiry were excluded from that question analysis. Patients were divided in two groups: Group A (office interview) and Group B (telephone interview). Student's t-test was used for independent samples, when comparing the scores in the GERD-HRQL questionnaire between groups A and B (all patients and separated by gender). Fisher's exact test was used to evaluate the answers between groups $\mathrm{A}$ and $\mathrm{B}$ regarding their willingness to do surgery again and their grade of symptom improvement. Results were considered significant when $P \leq 0,05$.

\section{RESULTS}

Group A was composed of $22(48.9 \%)$ male patients and $23(51.1 \%)$ females, whereas group B consisted of $19(42.2 \%)$ male patients and $26(57.8 \%)$ women.

The average GERD-HRQL score of men in group A was 4.09 (range 0-14). The women in this group had an average score of 8.39 (range $0-35$ ). In group B, male patients had an average score of 12.37 (range 0-50). Female patients in this group had an average score of 15.35 (range 0-50), as shown in Figure 2.

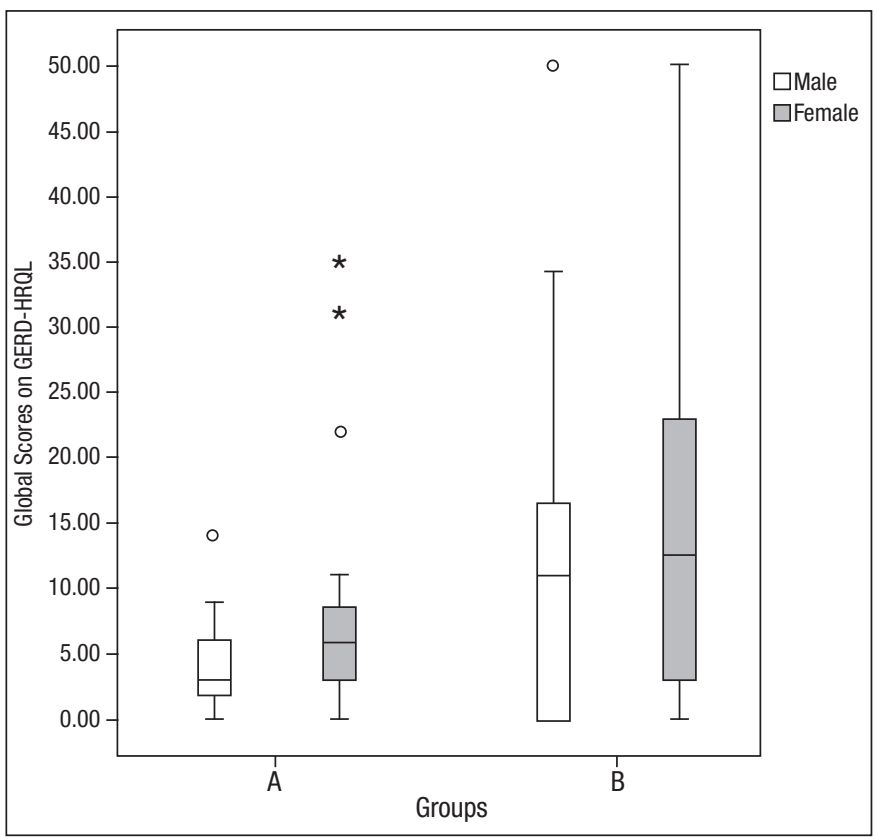

FIGURE 2. Boxplot of global scores in gastroesophageal reflux disease - Health Related Quality of Life (GERD-HRQL) - groups A (office interview) and B (telephone interview), by gender

Thirty-five $(77.8 \%)$ patients in group A reported satisfaction after surgery and $10(22.2 \%)$ were neutral. When surveyed about the possibility of doing the surgery again, $42(93.3 \%)$ patients said they would, and the remaining 3 $(6.7 \%)$ patients said they wouldn't. The average grade of symptom improvement, compared to preoperative, was 8.33 (range 4-10).

In group B, $36(80.0 \%)$ patients were satisfied with the operation, $1(2.2 \%)$ patient considered it neutral and $8(17.8 \%)$ 
patients were not satisfied with the outcome. Forty $(88.9 \%)$ patients said they would do the surgery again, and the average grade of symptom improvement was 8.17 (range $0-10$ ).

The results of the comparison of overall scores in GERD-HRQL between groups showed statistically lower score in group A (office interview) when compared to group B (telephone interview) in male patients $(P=0.018)$, female $(P=0.049)$ and both genders $(P=0.002)$ (Table 1). However, comparing other methods of quality of life evaluation, there was no statistical difference between groups $\mathrm{A}$ and $\mathrm{B}$ regarding patients choice of doing the surgery again $(P=0.714)$ and their grade of postoperative symptom improvement $(P=0.642)($ Table 2$)$.

TABLE 1. Higher patient scores in Gastroesophageal Reflux Disease - Health Related Quality of Life questionnaire in group B (telephone interview), compared to group A (office interview)*

\begin{tabular}{|c|c|c|c|c|c|}
\hline Group & Gender & $\mathrm{n}$ & Mean & Median & Standard deviation \\
\hline \multirow[t]{3}{*}{ A } & Male & 22 & 4.09 & 3.00 & 3.34 \\
\hline & Female & 23 & 8.39 & 6.00 & 9.05 \\
\hline & Both & 45 & 6.29 & 5.00 & 7.14 \\
\hline \multirow[t]{3}{*}{ B } & Male & 19 & 12.37 & 11.00 & 13.69 \\
\hline & Female & 26 & 15.35 & 12.50 & 14.57 \\
\hline & Both & 45 & 14.09 & 11.00 & 14.12 \\
\hline \multirow[t]{3}{*}{ Total } & Male & 41 & 7.93 & 5.00 & 10.37 \\
\hline & Female & 49 & 12.08 & 8.00 & 12.66 \\
\hline & Both & 90 & 10.19 & 6.00 & 11.80 \\
\hline
\end{tabular}

$P=0.002$ (both genders); $P=0.018$ (male patients); $P=0.049$ (female patients)

*According to Student's $t$-test

\section{DISCUSSION}

The current concepts of quality-of-life and well-being became popular from the '1960s and '1970s as a contrast to the former criteria of quality-of-life studies, which were predominantly quantitative and focused on economic aspects. According to Moreno and Pol, the concept of quality-of-life is inseparable from the personal experience that people go through and the physical and social conditions to which they have ${ }^{(9)}$. For Fleck et al., concern with the concept of quality-of-life demonstrates a movement within the human and biological sciences, and with the intent to expand the parameters beyond the control of symptoms and reduction in mortality or an increase in life expectancy ${ }^{(4)}$. In clinical trials, assessing quality-of-life was added as a third dimension being evaluated, in addition to efficacy and safety.

In patients who underwent laparoscopic Nissen fundoplication for GERD, the main goal of surgery is to improve patients symptoms and quality-of-life, since there is no scientific relevant evidence for the prevention of cancer of the esophagus and, much less, to reduction in mortality.

It is known that the overall satisfaction of patients undergoing laparoscopic Nissen fundoplication is high, above $90 \%$ at five years postoperatively ${ }^{(11)}$. This result is lower for patients with only atypical symptoms of the disease, about $70 \%{ }^{(6)}$. Better understanding of the pathophysiology of GERD, the advent of laparoscopic surgery, advances in surgical technique and greater attention in surgical indication can be credited as responsible for the success and wide acceptance of the procedure worldwide.

The evaluation of satisfaction of patients treated for GERD was described with the use of various tools in the literature. Some authors have developed questionnaires themselves without validation, according to the observations of each investigator. Initially, generic questionnaires on quality-

TABLE 2. Patient distribution according to their willingness to do surgery again and their grade of symptom improvement

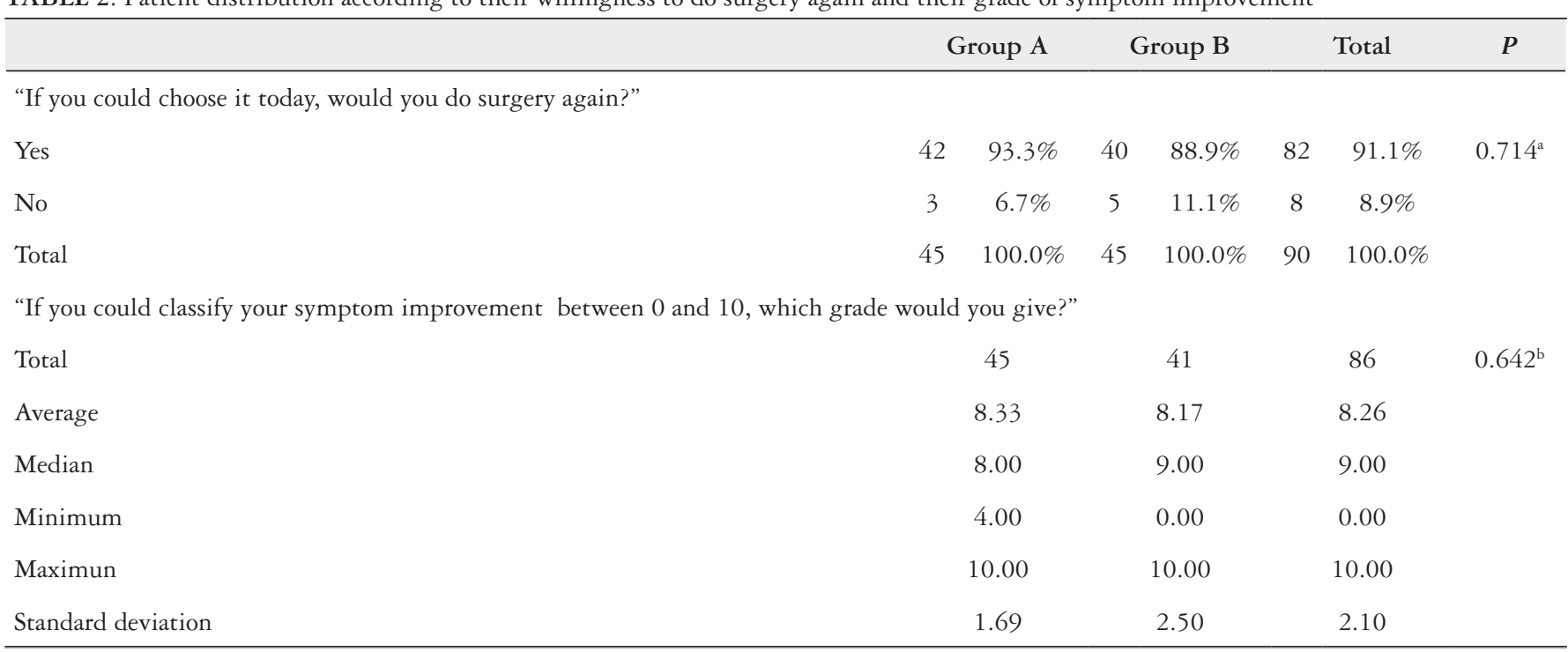

"Fisher's exact test ${ }^{\mathrm{b}} \mathrm{t}$-Student test for independent samples 
of-life, used for various diseases, were used to measure the satisfaction of patients operated for GERD.

In general, a tool assessing quality-of-life is considered adequate when it possesses three qualities ${ }^{(1)}$ :

- Validity - Is described as how much the tool can measure what is expected of it, and its ability to discriminate between groups with varying severity of disease

- Reliability - Is the ability of the instrument to produce similar results in repeated applications, in identical situations

- Responsiveness - How the assessment tool can detect changes in quality-of-life over time, and how it manages to keep its results when there are no changes in quality-of-life.

With the goal of developing a practical, concise and reliable tool for assessing the treatment of patients with GERD, whether medical, surgical or new therapeutic modalities, such as endoscopic, Vic Velanovich developed in 1996 the GERD-HRQL questionnaire ${ }^{(15)}$. This questionnaire, specific for GERD, has been tested and validated in English, using as reference and comparison criteria the SF-36 questionnaire, widely used in the literature to assess quality-of-life of patients suffering from various diseases in different medical specialties. This study demonstrated the superiority of the GERD-HRQL for evaluation of patients with GERD ${ }^{(13)}$.

There are five questionnaires in literature that assess comprehensively the symptoms and quality of life of patients with GERD. None of them, including GERD-HRQL, achieves measurement criteria considered ideal as an evaluation tool. One of the biggest criticisms to this questionnaire is that it does not evaluate atypical symptoms of the disease ${ }^{(1)}$. However, the fact that it has been validated by comparison to a generic questionnaire established in literature, includes assessment of the impact of medication on patients' lives, considers the impact of flatulence and bloating, frequent symptoms in patients operated for GERD, and has the simplicity and practicality of application ${ }^{(14)}$. These properties have made this a questionnaire of great value in the measurement of quality-of-life in surgical patients.

However, a questionnaire to be used in other languages, such as Portuguese, in our case, must be adapted to the culture and language of each country, adapting to the regional reality. The GERD-HRQL, among others, was validated by Pereira et al. in 2007 in Brazil and is considered a valid option, reliable, low-wear and easy to apply to patients ${ }^{(10)}$. As expected, it was necessary to adapt four words in its ques- tions, since the absolute translation thereof was difficult to be understood by patients.

In our study, there was a statistically significant difference as to the result obtained with the application of GERDHRQL questionnaire conducted in person and by telephone. Initially, we contacted 90 of our patients, but only 45 patients attended the hospital to answer the questionnaire, and the remaining 45 we could only administer it by telephone. Patients who were contacted by telephone had a higher score, showing the presence of more intense symptoms. At first we expected an opposite result to that found, since we believed that individuals with more symptoms would more often seek medical care. Moreover, considering that anti-reflux surgery is a procedure with high success rate, we know that many patients, as they have immediate and lasting improvement of symptoms postoperatively, ultimately do not adhere to a routine medical follow-up after surgery.

As the questionnaire was administered by the same investigator, both in person and by telephone, some difficulties with the telephone application of GERD-HRQL was observed. First, our patient population is comprised mostly by humble individuals with low level of education. Unfortunately, these characteristics were identified, but were not measured objectively. Also, in office, while we tried to make questions to patients without further explanation and detailing of their meaning, gestures and expressions appeared to facilitate their comprehension. In addition, some patients by telephone gave higher scores to the GERDHRQL questions by associating their current symptoms with surgery and GERD, but actually seemed to be suffering from other diseases that caused their discomfort. This became more evident when we added to our interview the question about the "grade of symptom improvement between $0-10$ " and if they "would do the surgery again?". On these two questions, there was no statistical difference between groups A and B. However, to confirm these findings, a personal re-interview is required with the patients in group $\mathrm{B}$, comparing the results.

\section{CONCLUSIONS}

The overall postoperative satisfaction was high. The GERD-HRQL questionnaire might not be suitable for application by telephone in our population, and based on other analyzes, the degree of satisfaction and quality of life of patients interviewed at the office or by telephone was similar. 
Kappaz GT, Sallum RAA, Szachnowicz S, Rocha JRM, Cecconello I. Avaliação da qualidade de vida após fundoplicatura laparoscópica à Nissen. Arq Gastroenterol. 2014,51(3):212-6.

RESUMO - Contexto - A avaliação da qualidade de vida após a cirurgia para a doença do refluxo gastroesofágico é fundamental, pois a melhora dos sintomas é o principal objetivo do tratamento. Objetivo - Verificar a satisfação dos pacientes após a cirurgia para doença do refluxo gastroesofágico, e comparar a aplicação ambulatorial e telefônica do questionário GERD-HRQL. Métodos - Cento e setenta e oito pacientes foram submetidos à fundoplicatura laparoscópica à Nissen. Noventa pacientes foram encontrados e 45 puderam comparecer ao ambulatório. Os demais 45 pacientes foram entrevistados por telefone. A qualidade de vida foi avaliada por três métodos: o questionário GERD-HRQL, traduzido para o Português; pergunta "Se você pudesse escolher hoje, faria a cirurgia novamente?"; e pergunta: "Se você pudesse classificar sua melhora dos sintomas entre 0 e 10, que nota você daria?" Os pacientes foram divididos em grupo A (entrevista ambulatorial) e B (entrevista telefônica). Resultados - A pontuação média do grupo A no questionário GERD-HRQL foi de 6,29, enquanto que no grupo B foi de $14,09(P=0,002)$. Não houve diferença estatística entre os grupos A e B em relação a escolha de fazer a cirurgia novamente $(P=0,714)$ e o grau de melhora dos sintomas no pós-operatório $(P=0,642)$. Conclusão - A satisfação geral dos pacientes no pós-operatório foi elevada. O questionário GERD-HRQL pode não ser adequado para aplicação por telefone na nossa população, e com base em outras análises, a satisfação e a qualidade de vida dos pacientes entrevistados no ambulatório ou por telefone foi semelhante.

DESCRITORES - Refluxo gastroesofágico. Fundoplicatura. Qualidade de vida.

\section{REFERENCES}

1. Chassany O, Holtmann G, Malagelada J, Gebauer U, Doerfler H, Devault K Systematic review: health-related quality of life (HRQOL) questionnaires in gastro-oesophageal reflux disease. Aliment Pharmacol Ther. 2008;27:1053-70.

2. Dallemagne B, Weerts J, Markiewicz S, Dewandre JM, Wahlen C, Monami B, Jehaes C. Clinical results of laparoscopic fundoplication at ten years after surgery. Surg Endosc. 2006;20:159-65.

3. Finks JF, Wei Y, Birkmeyer JD. The rise and fall of antireflux surgery in the United States. Surg Endosc. 2006;20:1698-701.

4. Fleck MP, Louzada S, Xavier M, Chachamovich E, Vieira G, Santos L, Pinzon V. Application of the Portuguese version of the instrument for the assessment of quality of life of the World Health Organization (WHOQOL-100). Rev Saude Publica. 1999;33:198-205.

5. Gee DW, Andreoli MT, Rattner DW. Measuring the effectiveness of laparoscopic antireflux surgery: long-term results. Arch Surg. 2008;143:482-7.

6. Kaufman JA, Houghland JE, Quiroga E, Cahill M, Pellegrini CA, Oelschlager BK. Long-term outcomes of laparoscopic antireflux surgery for gastroesophageal reflux disease (GERD)-related airway disorder. Surg Endosc. 2006;20:1824-30.

7. Kelly JJ, Watson DI, Chin KF, Devitt PG, Game PA, Jamieson GG. Laparoscopic Nissen fundoplication: clinical outcomes at 10 years. J Am Coll Surg. 2007;205:570-5.
8. Lundell L, Miettinen P, Myrvold HE, Pedersen SA, Liedman B, Hatlebakk JG, et al. Continued (5-year) followup of a randomized clinical study comparing antireflux surgery and omeprazole in gastroesophageal reflux disease. J Am Coll Surg. 2001;192:172-9; discussion 9-81.

9. Moreno E, Pol E. Nociones psicossociales para la intervención y la gestión ambiental. Barcelona: Publicaciones Universitat de Barcelona; 1999.

10. Pereira GI, Costa CD, Geocze L, Borim AA, Ciconelli RM, Camacho-Lobato L. Cross-cultural adaptation and validation for Portuguese (Brazil) of health related quality of life instruments specific for gastroesophageal reflux disease. Arq Gastroenterol. 2007;44:168-77.

11. Pessaux P, Arnaud JP, Delattre JF, Meyer C, Baulieux J, Mosnier H. Laparoscopic antireflux surgery: five-year results and beyond in 1340 patients. Arch Surg. 2005;140:946-51.

12. Rice TW, Blackstone EH. Surgical management of gastroesophageal reflux disease Gastroenterol Clin North Am. 2008;37:901-19.

13. Velanovich V. Comparison of generic (SF-36) vs. disease-specific (GERD-HRQL) quality-of-life scales for gastroesophageal reflux disease. J Gastrointest Surg. 1998;2:141-5.

14. Velanovich V. The development of the GERD-HRQL symptom severity instrument. Dis Esophagus. 2007;20:130-4.

15. Velanovich V, Vallance SR, Gusz JR, Tapia FV, Harkabus MA. Quality of life scale for gastroesophageal reflux disease. J Am Coll Surg. 1996;183:217-24. 